\title{
Well-of-the-well (WOW) versus polyester mesh (PM): a comparison of single-embryo culture systems in bovines
}

\author{
Pozo dentro de pozo (WOW) versus tela de poliéster (PM): una comparación de sistemas de cultivo \\ individual de embriones bovinos
}

\begin{abstract}
Well-of-the-well (WOW) versus malha de poliéster (PM): uma comparação de sistemas de cultura de um único embrião em bovinos
\end{abstract}

\author{
Daniel Contreras-Benicio D; Beatriz Elena Castro-Valenzuela iD; Juan Alberto Grado-Ahuir (D); \\ María Eduviges Burrola-Barraza*iD.
}

Facultad de Zootecnia y Ecología, Universidad Autónoma de Chihuahua. Chihuahua, Chihuahua, México.

To cite this article:

Contreras-Benicio D, Castro-Valenzuela BE, Grado-Ahuir JA, Burrola-Barraza ME. Well-of-the-well (WOW) versus polyester mesh (PM): a comparison of single-embryo culture systems in bovines. Rev Colomb Cienc Pecu 2022; 35(2): 93-108. DOI: https://doi.org/10.17533/udea.rccp.v35n2a03

\begin{abstract}
Background: Mexico is innovating in the livestock industry through in vitro generation of bovine embryos with technologies such as well-of-the-well (WOW) and polyester mesh (PM) single-embryo culture systems. These techniques allow to maintain embryos in separate areas of a shared culture medium. Objective: To compare the quantity and quality of bovine embryos produced in WOW and PM culture systems versus the conventional (CG) culture system. Methods: In total, 345 embryos fertilized in vitro were evaluated for blastocyst yield in the three culture systems. To count blastocyst cell numbers, 69 embryos in each system were differentially stained for trophectoderm (TE), inner cell mass (ICM), and apoptotic cells. A qPCR gene expression analysis was performed for embryos in all three systems. Results: The WOW, PM and CG systems developed similar amount of blastocysts $(41,35$ and $36 \%$, respectively; $p>0.05)$. Blastocysts in all three systems showed adequate amounts of ICM and apoptotic cells. Blastocysts in the PM system showed a greater number of TE cells [63.7 versus $58.6 \%$ in the CG system $(\mathrm{p}<0.05)]$. Relative mRNA expression of the embryonic genes POUF5F1, GNAS and TP53 did not differ significantly among systems $(\mathrm{p}>0.05)$. The $A T P 5 B$ expression was higher in WOW than in PM ( $<<0.05)$, but similar to CG ( $>0.05)$. The TJP3 expression was higher in PM than in WOW and CG $(\mathrm{p}<0.05)$. Expression of ID2 and CLDN4 was higher in WOW than in PM and CG $(\mathrm{p}<0.05)$. The biplot graphic from Principal Component Analysis (PCA) revealed that CG was located near degenerated embryos, whereas PM was located near arrested embryos, larger ICM and TE, and TJP3 expression. The WOW was located toward blastocysts, morulae, and expression of CLDN4, ID2 and GNAS. Conclusion: Compared with CG, both the $\mathrm{PM}$ and WOW systems are good options for culturing single embryos in the bovine model. Moreover, the PCA results suggest that embryos developed in the WOW system have greater capacity for generating blastocysts with increased ability to form TE and ICM layers, which might improve implantation.
\end{abstract}

Received: February 1, 2021; accepted: September 14, 2021

*Corresponding author. Perif. R. Aldama Km 1, 31031 Chihuahua, Mexico. Phone:+526 144340303.E-mail: $\underline{\text { mburrola1@uach.mx }}$

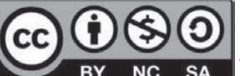
(c) 2022 Universidad de Antioquia. Publicado por Universidad de Antioquia, Colombia. 
Keywords: bovine embryo; embryo quality; embryo recovery; in vitro culture; in vitro embryo production; polyester mesh culture; single-embryo culture; well-of-the-well culture.

\section{Resumen}

Antecedentes: México está innovando en la industria ganadera a través de la generación in vitro de embriones bovinos con tecnologías de cultivo individual como lo son Pozo dentro de Pozo (WOW) y Malla de Poliéster (PM). Estos mantienen los embriones en áreas separadas mientras comparten un mismo medio de cultivo celular. Objetivo: Comparar la cantidad y calidad de embriones bovinos producidos en los sistemas WOW y PM contra el sistema de cultivo convencional en grupo (CG). Métodos: En total se evaluaron 345 embriones fertilizados in vitro para determinar la producción de blastocistos generados en los tres sistemas. Para contar el número de células por blastocisto, 69 embriones en cada sistema se tiñeron diferencialmente para trofectodermo (TE), masa celular interna (ICM) y células apoptóticas. Se realizó un análisis de expresión génica por qPCR de los embriones obtenidos en los tres sistemas. Resultados: Los sistemas WOW, PM y CG desarrollaron similares cantidades de blastocistos (41, 35 y 36\%, respectivamente; $\mathrm{p}>0,05)$. Los blastocistos en los tres sistemas mostraron cantidades adecuadas de ICM y células apoptóticas. Los blastocistos en el sistema PM mostraron un mayor número de células TE [63,7\% versus $58,6 \%$ en el sistema $\mathrm{CG}(\mathrm{p}<0,05)]$. La expresión relativa de mRNA de los genes embrionarios POUF5F1, GNAS y TP53 no difirió significativamente entre los sistemas ( $\mathrm{p}>0,05)$. La expresión de $A T P 5 B$ fue mayor en WOW que en PM ( $<<0,05)$, pero similar a CG $(\mathrm{p}<0,05)$. La expresión de TJP3 fue mayor en PM que en WOW y CG $(\mathrm{p}<0,05)$. La expresión de $I D 2$ y $C L D N 4$ fue mayor en WOW que en PM y CG $(\mathrm{p}<0,05)$. El gráfico de biplot del análisis de componentes principales reveló que CG se encontró cerca de embriones degenerados, mientras que PM se encontró cerca de embriones en arresto, ICM, TE, y TJP3. El WOW se localizó hacia blastocistos, mórulas y la expresión de CLDN4, ID2 y GNAS. Conclusión: En el modelo bovino los sistemas PM y WOW son buenas opciones para cultivar embriones individuales, ya que se obtienen resultados muy similares a los obtenidos con el sistema CG. Además, los resultados de PCA sugieren que los embriones individuales desarrollados en el sistema WOW generan blastocistos con mayor capacidad de formar TE e ICM, lo que podría mejorar su éxito de implantación.

Palabras clave: calidad embrionaria; cultivo de malla de poliéster; cultivo individual; cultivo in vitro; cultivo pozodentro-de-pozo; embriones bovinos; producción in vitro de embriones; recuperación de embriones.

\section{Resumo}

Antecedentes: O México está inovando na indústria pecuária por meio da geração in vitro de embriões bovinos com tecnologias de cultura de embriões individuais, bem como em poço (WOW) e malha de poliéster (PM). Estes mantêm os embriões em áreas separadas, enquanto compartilham o mesmo meio de cultura de células. Objetivo: Comparar a quantidade e a qualidade de embriões bovinos produzidos nos sistemas de cultura WOW e PM com o sistema convencional de cultura em grupo (CG). Métodos: No total, 345 embriões fertilizados in vitro foram avaliados para determinar a produção de blastocistos gerados nos três sistemas. O número de células por blatocisto foi contado, 69 embriões em cada sistema foram diferencialmente corados para trofectoderme (TE), massa celular interna (ICM) e células apoptóticas. Uma análise de expressão gênica qPCR foi realizada para os embriões obtidos nos três sistemas. Resultados: Os sistemas WOW, PM e CG desenvolveram quantidades semelhantes de blastocistos (41, 35 e 36\%, respectivamente; $p>0,05)$. Os blastocistos nos três sistemas mostraram quantidades adequadas de ICM e células apoptóticas. Os blastocistos no sistema PM mostraram um número maior de células TE [63,7 versus 58,6\% no sistema $\mathrm{CG}(\mathrm{p}<0,05)]$. A expressão relativa do mRNA dos genes embrionários POUF5F1, GNAS e TP53 não diferiu significativamente entre os sistemas ( $\mathrm{p}>0,05)$. A expressão de $A T P 5 B$ foi maior no WOW do que no PM ( $\mathrm{p}<0,05)$, mas semelhante ao GC ( $<<0,05)$. A expressão de TJP3 foi maior no PM do que no WOW e CG (p<0,05). A expressão de ID2 e CLDN4 foi maior no WOW do que no PM e CG $(\mathrm{p}<0,05)$. O gráfico biplot da análise de componentes principais revelou que $\mathrm{CG}$ foi encontrado próximo a embriões degenerados, enquanto PM foi encontrado próximo a embriões presos, ICM, TE e TJP3. WOW foi encontrado para ter blastocistos, mórulas e a expressão de CLDN4, ID2 e GNAS. Conclusão: Em comparação com o CG, os sistemas PM e WOW são boas opções para a cultura de embriões individuais no modelo bovino. Além disso, os resultados da PCA sugerem que embriões individuais desenvolvidos no sistema WOW têm maior capacidade de desenvolver blastocistos com maior capacidade de formar as camadas TE e ICM, o que poderia melhorar seu sucesso de implantação.

Palavras-chave: cultura em tela de poliéster; cultura individual; cultura in vitro; cultura well-in-well; embriões bovinos; qualidade embrionária; produção de embriões in vitro; recuperação embrionária. 


\section{Introduction}

A priority for most Latin American countries, including Mexico, is to develop an agricultural sector that is capable of safely and efficiently producing enough food to meet population demands. This objective can be reached through innovation of technologies used to produce bovine embryos, thus allowing to improve the competitiveness of the meat and dairy industry. In vitro embryo production has become an excellent tool to investigate reproduction mechanisms and is used in procedures for gene editing, cloning by somatic cell nuclear transfer (SCNT), and production of embryonic stem cells (Hansen, 2020a). Conventional evaluation of embryos cultured in vitro is based on visual assessment of cell morphology, which may be subjective since it depends on the technician's experience and judgement. This is reflected in the low pregnancy rates $(\sim 50 \%)$ recorded for embryos selected under this criterion (Ealy et al., 2019; Hansen, 2020b; Lopes et al., 2020). Additional criteria for embryo quality include: number of cells in the inner cell mass (ICM) and trophectoderm (TE), incidence of apoptosis, eclosion capacity, chromosome abnormalities, and expression of specific genes, among others (Sugimura et al., 2012). Evaluation of these features requires that the embryos are correctly identified, which is challenging to achieve in conventional group (CG) culture since it is conducted with groups of approximately 50 embryos in the same culture dish (Fujita et al., 2006; Salvador et al., 2011). A potential solution to this issue is single-embryo culture; however, several studies (Marianowski et al., 2007; Salvador et al., 2011) have been unsuccessful at single-embryo production because individual embryos do not benefit from the paracrine and autocrine factors secreted by multiple embryos and accumulated in CG culture (Fujita et al., 2006; Gopichandran and Leese, 2006; Paria and Dey, 1990). Therefore, if quality selection is desired, a cell culture system that allows identifying embryos without sacrificing the benefits of CG culture is necessary. A way to achieve this is to sequester single embryos in the same culture medium; and two systems, well-of-the-well (WOW) and polyester mesh (PM), have been used with good results in species such as cattle (Sugimura et al., 2010; Vajta et al., 2000), pigs (Vajta et al., 2008), mice (Komori et al., 2012), and humans (Vajta et al., 2010a; Vajta et al., 2010b). Therefore, the objective of this work was to compare WOW and PM single-embryo culture systems versus CG system as alternatives for generating betterquality bovine embryos.

\section{Materials and Methods}

\section{Ethical considerations}

All experiments were conducted in accordance with the institutional code for Bioethics Regulation for Animal Welfare of Universidad Autónoma de Chihuahua, México (case number: CFTZyE-Acta-101/2015:ACUERDO 4.2).

\section{$\underline{\text { In vitro oocyte maturation }}$}

Bovine ovaries were collected in a Mexican slaughterhouse (Tipo Inspección Federal -TIF366) and transported within 2 hours to the laboratory in sterile sodium chloride $0.15 \mathrm{M}$ $\left(22-25^{\circ} \mathrm{C}\right)$. The cumulus-oocyte complexes (COC) in the ovaries were aspirated from less than $10 \mathrm{~mm}$ diameter follicles using a BD $18 \mathrm{G} \mathrm{x}$ $1 \frac{1}{2}$ PrecisionGlide needle (Becton, Dickinson and Company, Franklin Lakes, NJ, USA) with 50 $\mathrm{mmHg}$ pressure of vacuum suction (WOB-L ${ }^{\circledR}$ Dry Vacuum Pumps, Standard-Duty, Welch ${ }^{\circledR}$, Denver, CO, USA). All chemical compounds used for media culture were from Sigma ( $\mathrm{St}$ Louis, MO, USA). The chemically defined CDM medium was as follows: $710 \mathrm{mM} \mathrm{NaCl}, 60 \mathrm{mM}$ $\mathrm{KCl}, 10 \mathrm{mM} \mathrm{KH} \mathrm{PO}_{4}, 5 \mathrm{mM}$ Na-citrate, $5 \mathrm{mM}$ $\mathrm{NaHCO}_{3}, 2 \mathrm{mM} \mathrm{CaCl}, 4.9 \mathrm{mM}$ glycine, $1 \mathrm{mM}$ alanyl-glutamine, $20 \mathrm{mMHEPES}, 10 \mathrm{mM}$ sodium L-lactate, $0.5 \mathrm{mM}$ Na-pyruvate, $0.5 \mathrm{mM} \mathrm{MgSO}_{4}$, $67 \mathrm{mM}$ non-essential amino acids, and $25 \mu \mathrm{g} /$ $\mathrm{mL}$ gentamycin. The COC were washed twice in a chemically semi-defined medium for oocyte handling, H-CDM-M [CDM supplemented with $0.5 \mathrm{mM}$ D-fructose, $2.5 \%$ fatty acid-free bovine serum albumin (BSA), $22.5 \mathrm{mM} \mathrm{NaCl}$ and 20 $\mu \mathrm{g} / \mathrm{mL}$ heparin $\mathrm{Na}$ salt] and were selected for study if at least three coats of cumulus cells were 
detected under a Leica MS5 stereomicroscope (Leica Microsystems, Wetzlar, Germany). The COC were cultured in four-well plates (Nunc, Thermo Scientific, Rockford, IL, USA). Briefly, groups of 50 COC per well were maintained in $1 \mathrm{~mL}$ of chemically semi-defined medium for in vitro maturation, M-CDM (CDM supplemented with $2 \mathrm{mM}$ D-fructose, $2.77 \mathrm{mM}$ myo-inositol, $0.1 \mathrm{mM}$ taurine, $5 \%$ fatty acid free BSA, $15 \mathrm{ng} /$ $\mathrm{mL}$ follicle stimulating hormone (FSH), $1 \mu \mathrm{g} / \mu \mathrm{L}$ luteinizing hormone $(\mathrm{LH}), 0.1 \mu \mathrm{g} / \mu \mathrm{L}$ estradiol$17 \beta, 50 \mathrm{ng} / \mu \mathrm{L}$ epidermal growth factor (EGF), and $0.1 \mathrm{mM}$ cysteamine) at $38.5^{\circ} \mathrm{C}$ with $5 \% \mathrm{CO}_{2}$ at $100 \%$ humidity for $24 \mathrm{~h}$.

\section{In vitro fertilization}

After $24 \mathrm{~h}$ ofCOC in vitro maturation, four-well plates (Nunc, Thermo Scientific, Rockford, IL, USA) were prepared, with each well containing $430 \mu \mathrm{L}$ of chemically defined medium for in vitro fertilization, F-CDM (CDM supplemented with $0.5 \mathrm{mM}$ D-fructose, $2 \mathrm{mM}$ caffeine, $5 \% \mathrm{BSA}$ and $2 \mu \mathrm{g} / \mathrm{mL}$ heparin and $14 \mathrm{mM} \mathrm{NaCl}$ ). One $\mathrm{mL}$ of purified water was added to the center of each four-well plate. Oocytes at the meiosis II (MII) stage were transferred in groups of 50 to each well. Semen from an Angus bull was used for IVF, as follows: $0.5 \mathrm{~mL}$ straws were thawed at $35^{\circ} \mathrm{C}$ for $35 \mathrm{~s}$. The semen was centrifuged in a Percoll gradient solution (45 and 90\%) at $400 \times \mathrm{g}$ for 20 min. The resulting pellet was re-suspended in 4.5 $\mathrm{mL}$ F-CDM and centrifuged again (400 x $g$ for $5 \mathrm{~min}$ ). After the medium was aspirated, the cell concentration was adjusted to $1 \times 10^{6}$ sperm per $\mathrm{mL}$, and $50 \mu \mathrm{L}$ of this sperm dilution solution was added to each well and the plates were incubated at $38.5{ }^{\circ} \mathrm{C}$ in $5 \% \mathrm{CO}_{2}$ in humidity-saturated air. Eighteen hours post-IVF, the potential embryos were transferred to $0.5 \mathrm{~mL}$ microcentrifuge tubes containing $100 \mu \mathrm{L}$ of chemically defined medium for handling of early embryos, H-CDM-1 (CDM supplemented with $0.5 \mathrm{mM}$ D-fructose, $2.5 \%$ fatty acid free BSA and $22.5 \mathrm{mM} \mathrm{NaCl}$ ). Then, they were vortexed for $1 \mathrm{~min}$ to remove cumulus cells. Then 50 embryos were placed in $500 \mu \mathrm{L}$ of chemically defined medium for in vitro culture of early embryos, CDM-1 (CDM supplemented with $0.5 \mathrm{mM}$ D-fructose, $2.77 \mathrm{mM}$ myo-inositol,
$0.1 \mathrm{mM}$ taurine, 5\% BSA, $0.1 \mathrm{mM}$ EDTA and 1 $\mathrm{mM} \mathrm{NaCl}$ ) in each well of a four-well plate. One $\mathrm{mL}$ of distilled water was added to the center of the plate. After $60 \mathrm{~h}$ at $39{ }^{\circ} \mathrm{C}$ in an atmosphere of $5 \% \mathrm{CO}_{2}, 5 \% \mathrm{O}_{2}$, and $90 \% \mathrm{~N}_{2}$ in humiditysaturated air, embryos at the eight-cell stage were incubated and selected in chemically defined medium for handling of late embryos, H-CDM-2 (CDM supplemented with $2 \mathrm{mM}$ fructose, $2.5 \%$ BSA, $1.47 \mathrm{mM}$ essential amino acids and 26.5 $\mathrm{mM} \mathrm{NaCl}$ ). Following selection, embryos were transferred to $400 \mu \mathrm{L}$ of chemically defined medium for in vitro culture of embryos, CDM-2 (CDM supplemented with $2 \mathrm{mM}$ D-fructose, $2.77 \mathrm{mM}$ myo-inositol, $1.47 \mathrm{mM}$ essential amino acids, 5\% BSA and $5 \mathrm{mM} \mathrm{NaCl}$ ) in four-well plates. One $\mathrm{mL}$ of purified water was added to the center hole of the plate and it was then incubated with $5 \% \mathrm{CO}_{2}, 5 \% \mathrm{O}_{2}$, and $90 \% \mathrm{~N}_{2}$ in humiditysaturated air at $39{ }^{\circ} \mathrm{C}$ for four days. Subsequently, 8-cell embryos were selected and maintained in H-CDM-2 medium and were organized into 20 embryo groups to be cultured in the WOW, PM and CG systems.

\section{Single-embryo culture with shared medium}

Two in vitro single-embryo culture systems, PM and WOW, were used with the purpose of generating individual areas to accommodate an embryo with an approximate diameter of $75 \mathrm{~lm}$, and with a $165-1 \mathrm{~m}$ separation between them, as reported by Gopichandran and Leese (2006).

The PM system was implemented as reported by Somfai et al. (2010), with some modifications. A polyester mesh (07-300/36, Sefar, Heiden, Switzerland), whose interwoven threads generate areas with 136 I $\mathrm{m}$ diameter, each space separated by $200 \mathrm{~lm}$, were cut into $1.5 \mathrm{~mm} \times 2 \mathrm{~mm}$ pieces. These pieces of mesh were placed at the bottom of each well of the four-well dish, and each embryo was placed in the space created by the interwoven threads (Figure 1A).

The WOW experiments were conducted as reported by Vajta et al. (2008) with some modifications, as follows: in four-well plates containing $400 \mu \mathrm{l}$ of CDM-2 medium, micro- 
wells were created at the bottom of the well by applying mechanical pressure using an aggregation needle (DN- 09/B, BLS ${ }^{\circledR}$ Biological Laboratory Equipment Maintenance and Service Ltd., Budapest, Hungary). The resulting microwells were $220 \mathrm{~lm}$ in diameter, each separated by a distance of $2481 \mathrm{~m}$. Twenty micro-wells were formed in each well of the four-well plate, guided by a template placed on the outside of each well. This template defines an array represented by the letters a, b, c, d and e at the top, and the numbers 1, 2, 3 and 4 on the left side (Figure 1B).

Differential staining: trophectoderm (TE) and inner cell mass (ICM)

Blastocysts were washed three times in $0.1 \%$ polyvinylpyrrolidone in phosphatebuffered saline (PBS-PVP) and permeabilized by incubation for $20 \mathrm{~s}$ in $0.2 \%$ Triton $\mathrm{X}-100$ in PBS-PVP. The blastocysts were then washed three times in PBS-PVP, and transferred to PBSPVP containing $100 \mu \mathrm{g} / \mathrm{ml}$ propidium iodide to stain the TE cells, incubating them in complete darkness at $37{ }^{\circ} \mathrm{C}$ in a humid environment for $5 \mathrm{~min}$. The blastocysts were then washed three times in PBS-PVP. To fix the blastocysts and stain the ICM cells, the embryos were incubated for $30 \mathrm{~min}$ in 4\% paraformaldehyde (PFA) solution containing $10 \mu \mathrm{g} / \mathrm{ml}$ Hoechst 33258, and finally were washed three times in PBS-PVP.

\section{TUNEL procedure for cell apoptosis detection}

Embryos were washed three times in PBS-PVP, then transferred to a 96-well plate containing $100 \mu \mathrm{l}$ PBS-PVP and $100 \mu 1$ 4\% PFA, and incubated for $60 \mathrm{~min}$ at $15-25^{\circ} \mathrm{C}$. Embryos were then washed in another well with $200 \mu \mathrm{l}$ PBS-PVP. They were then permeabilized by incubation for $5 \mathrm{~min}$ in ice $\left(2-8^{\circ} \mathrm{C}\right)$ in a freshly prepared $0.1 \%$ Triton X-100 solution in $0.1 \%$ sodium citrate, and then washed three times in PBS-PVP. For TUNEL staining of the blastocysts, an In Situ Cell Death Detection Kit Fluorescein (Roche Diagnostics, Indianapolis, IN, USA) was used following the manufacturer's instructions.

A
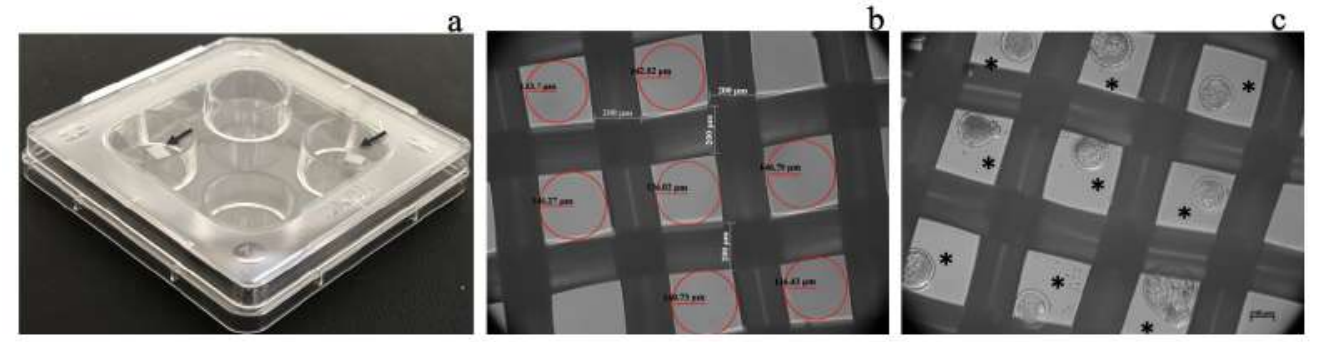

B
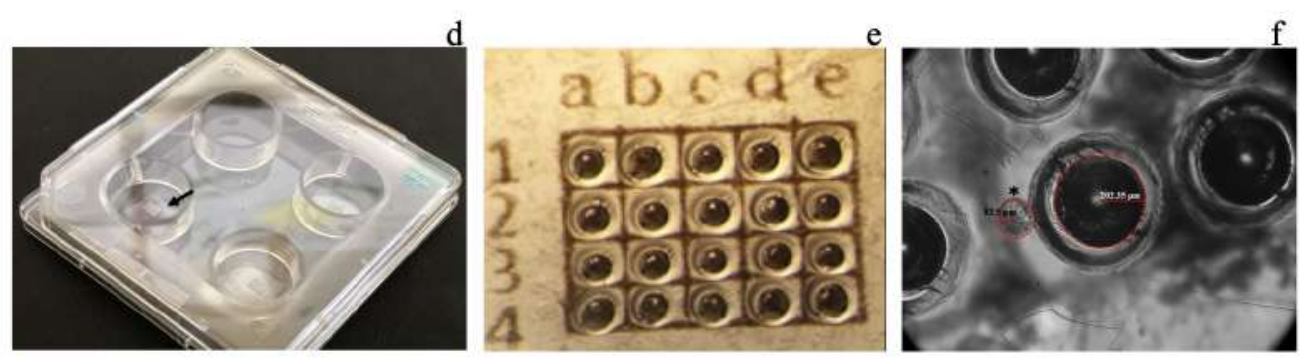

Figure 1. Prototypes of single-embryo cell culture. A. Polyester mesh (PM): a. 4-well dish, the black arrows indicate the microwells inside the well; b. View of PM; c. Blastocysts cultured individually in PM. B. Well-of-the-well (WOW): d. 4-well dish, the black arrow indicates the micro-wells inside the well; e. Micro-well template; $f$. View of micro-wells. In $b$ and $f$, the red circles indicate the micro-well area. In $\mathrm{c}$ and $\mathrm{f}, *$ indicates a blastocyst. The images in $\mathrm{b}, \mathrm{c}$, e and $\mathrm{f}$ were taken with an Axiovert CFL40 microscope (Carl Zeiss, Oberkochen, Germany) using 10× phase contrast. 
Permeabilized blastocysts were incubated in the dark in TUNEL reaction solution (1:10 dilution of terminal deoxynucleotidyl transferase enzyme in labeling solution with deoxynucleotidyl triphosphates, dNTPs) for $60 \mathrm{~min}$ at $37{ }^{\circ} \mathrm{C}$. For each TUNEL procedure, positive control embryos were treated with DNase I $(3 \mathrm{U} / \mathrm{mL})$ for $10 \mathrm{~min}$ at $25^{\circ} \mathrm{C}$, then subjected to the TUNEL reaction; for the negative control, the embryos were incubated in the absence of the terminal deoxynucleotidyl transferase enzyme.

\section{Blastocyst mounting and microscopy}

Blastocysts were placed on a slide in a 10- /L drop of glycerol and the labeling was observed using an Axio Imager M2 fluorescence microscope (Carl Zeiss, Inc. Göttingen, Germany) at $565 \mathrm{~nm}$ for apoptosis, $455 \mathrm{~nm}$ for nuclear staining of ICM (Hoechst 33258), and $617 \mathrm{~nm}$ for nuclear staining of TE (propidium iodide). Images were acquired using AxioVision Software and AxioCam MRm digital Camera (Carl Zeiss, Inc. Göttingen, Germany).

\section{Gene expression analysis via qPCR assay}

Total RNA of 25 embryos was isolated using the TRIzol reagent (Invitrogen, Carlsbad, CA, USA) according to the manufacturer's instructions, and stored at $-80{ }^{\circ} \mathrm{C}$ until used for cDNA synthesis. For all samples, the RNA concentration was determined by measuring absorbance at $260 \mathrm{~nm}$ using a NanoDrop spectrophotometer (NanoDrop Technologies, Thermo Fisher Scientific, Inc., Wilmington, DE, USA). Purity of nucleic acid was determined by calculating the ratio of absorbance between 260 and $280 \mathrm{~nm}$. The cDNA synthesis was performed using a High-Capacity RNA-to-cDNA kit (Applied Biosystems, Foster City, CA, USA) following the manufacturer's instructions using a mixture of $2 \mu \mathrm{g}$ of RNA. The reactions were placed in a thermocycler (Corbett Research, San Francisco, CA, USA) under the following program: $60 \mathrm{~min}$ at $37^{\circ} \mathrm{C}, 5 \mathrm{~min}$ at $95{ }^{\circ} \mathrm{C}$ to deactivate the enzyme, and kept at $4{ }^{\circ} \mathrm{C}$ until use. The concentration of obtained cDNA was determined by measurement of absorbance at
$260 \mathrm{~nm}$ using a NanoDrop spectrophotometer (NanoDrop Technologies, Thermo Fisher Scientific, Inc., Wilmington, DE, USA), and the purity of the nucleic acid was determined by calculating the ratio of absorbance between 260 and $280 \mathrm{~nm}$. The cDNA was stored at $-20^{\circ} \mathrm{C}$ until further use. For the analysis of gene expression, all reactions were performed using Real Time StepOne equipment (Applied Biosystems, Carslsbad, CA, USA). Amplification reagents for specific genes were obtained by using the TaqMan Universal Master Mix II and TaqMan Gene Expression Assays (Applied Biosystems, Foster City, CA, USA) for POUF5F1 (Bt03223846 g1), ATP5B (Bt03216727 $\mathrm{m} 1), \quad$ ID2 (Bt03220879_m1), MATER (Bt03218033_m1), GNAS (Bt03251812_g1), TJP3 (Bt03237880_m1), TP53 (Bt03223222 m19) and CLDN4 (Bt04318530_s1), including the FAM reporter for the genes quantified. The reactions were performed according to the manufacturer's protocol; each reaction contained $50 \mathrm{ng}$ cDNA, and the quantification of the expression of these genes was normalized to the endogenous GADPH gene (Bt3210913_g1); the results show relative abundance, calculated according to the $2-{ }^{\Delta \mathrm{Ct}}$ method, where $\otimes \mathrm{Ct}$ was generated by subtracting the reference gene $\mathrm{Ct}$ value from that of the target gene (Livak and Schmittgen, 2001).

\section{Statistical analysis}

All statistical analyses were performed using XLSTAT Software (Addinsoft, New York, NY, USA). The data for degenerated and arrested embryos, morulae, blastocysts, TE and ICM are expressed as percentage values. The gene expression data are given as $2-\Delta \mathrm{Ct}$ relative abundance. The normality of the data was confirmed with the Jarque-Bera test, and nonnormal data were transformed with BOX-COX. Normally distributed data were subjected to one-way ANOVA and means comparison was obtained by Tukey's test. The level of statistical significance was set at $p<0.05$. All values are presented as means with their corresponding standard error. 
To analyze the relationship between culture system and number of cells, type of embryo, and gene expression results, the Spearman correlation was applied, followed by a Principal Component Analysis (PCA), where the principal components (PC) were rotated with the Equamax method and the results shown in a biplot graphic.

\section{Results}

\section{Comparison between culture systems}

Figure 2 compares the WOW and PM singleembryo culture systems against the CG culture in terms of embryo development. The percentage of blastocysts was similar in all systems (41 \pm $4.35 \%$ in WOW, $35 \pm 3.65 \%$ in PM and $36 \pm$ $6.0 \%$ in $C G ; p>0.05)$. The same was observed for the embryos that reached the morula stage (29 $\pm 5.76 \%$ in WOW, $26 \pm 5.5 \%$ in PM and $27 \pm 6.7 \%$ in $\mathrm{CG} ; \mathrm{p}>0.05)$. The percentage of arrested embryos was similar in all systems (24 $\pm 6.2 \%$ in PM, $20 \pm 4.11 \%$ in WOW and $20 \pm 4.13 \%$ in $\mathrm{CG} ; \mathrm{p}>0.05)$. The production of degenerated embryos did show a significant difference; the WOW system produced fewer degenerated embryos compared to the other two methods $(11 \pm 0.54 \%$ versus $15 \pm 1.8 \%$ in $C G$ and $17 \pm 2.7 \%$ in $\mathrm{PM}$; $\mathrm{p}<0.05)$.

\section{Effect of culture system on blastocyst cell numbers}

To examine the effect of culture method on cellular composition of the embryo, we counted the number of cells in the ICM and TE, and the number of apoptotic cells (Table 1). Embryos cultured in all systems had similar number of total cells $(81.3 \pm 4.0$ in PM, 74.4 \pm 4.5 in WOW, $68.8 \pm 3.6$ in $\mathrm{CG}, \mathrm{p}>0.05)$. Embryos in the three culture systems had similar percentage of ICM $(41.4 \pm 1.7$ in GC, $36.3 \pm 1.3$ in PM and $38.8 \pm$ 1.8 in WOW, $\mathrm{p}>0.05$ ). Embryos in the PM system had a significantly higher proportion of TE cells $(63.7 \pm 3.1 \%)$ compared to those in the CG system $(58.6 \pm 2.6 \%, \mathrm{p}<0.05)$, but not compared to the WOW system $(61 \pm 3.2 \%, \mathrm{p}>0.05)$. The $\mathrm{ICM} / \mathrm{TE}$ ratio was very close in all systems $(0.7$ \pm 0.06 in GC and WOW, and $0.6 \pm 0.03$ in PM).

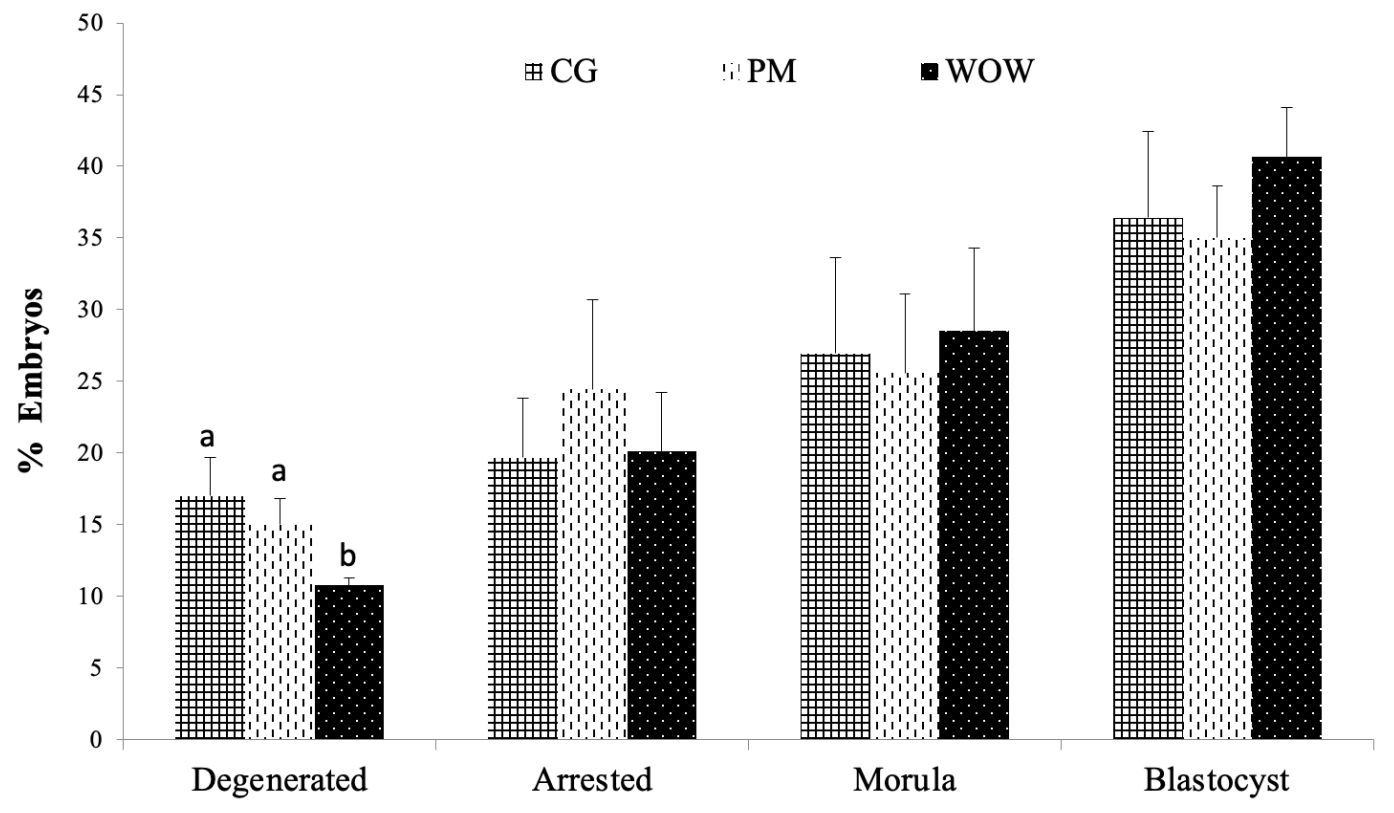

Figure 2. Comparison between the type of embryo developed as of day 7 post-IVF in each culture type: conventional culture in groups (CG), polyester mesh (PM), and well-of-the-well (WOW). Data are shown as means $\square$ standard error of the percentage of analyzed embryos. In total, 345 embryos distributed in six independent repetitions were evaluated for the three culture types $(\mathrm{CG}=117, \mathrm{PM}=115$ and $\mathrm{WOW}=113)$. 
Regarding the formation of apoptotic cells, embryos in the three culture systems presented very similar numbers, with approximately 2 apoptotic cells for each blastocyst evaluated.

\section{Effect of culture system on relative expression of embryonic genes}

The relative mRNA expression levels of embryonic genes POUF5F1, GNAS and TP53 did not show significant differences between WOW, PM and CG culture systems. However, expression of ATP5B gene was higher $(\mathrm{p}<0.05)$ in WOW embryos than in PM embryos. On the other hand, expression of TPJ3 gene was higher in PM system compared to $\mathrm{CG}$ and WOW systems $(p<0.05)$. Likewise, gene expression of
ID2 and CLDN4 was higher in WOW culture than in PM and CG systems $(\mathrm{p}<0.05)$. Regarding the expression of maternally expressed MATER gene (a negative control), it was negative in all three culture systems (Figure 3 ).

Correlation between cell culture system, type of embryo developed, apoptosis, and embryonic gene expression

Principal component (PC) analysis was used to investigate relationships between cell culture systemsand thevariousembryoparametersstudied, and two PCs were obtained: $\mathrm{PC} 1$ absorbed $53.16 \%$ of the variables, while PC2 absorbed 46.84\%; together they absorbed $100 \%$ of the variables.

Table 1. Effect of the culture system on the number of cells in blastocysts.

\begin{tabular}{ccccccc}
\hline \multirow{2}{*}{$\begin{array}{c}\text { Culture } \\
\text { system }\end{array}$} & $\begin{array}{c}\text { Blastocysts } \\
\text { tested }\end{array}$ & \multicolumn{5}{c}{ Number of cells per blastocyst } \\
\cline { 3 - 7 } & & $\mathbf{N}^{*}$ & ICM (\%) & TE (\%) & ICM/TE & Apoptotic (\%) \\
\hline \multirow{2}{*}{ PM } & 23 & $88.8 \pm 3.6$ & $28.5(41.4 \pm 1.7)$ & $40.4(58.6 \pm 2.6)^{\mathrm{a}}$ & $0.7 \pm 0.06$ & $2.2(3.2 \pm 0.6)$ \\
WOW & 26 & $74.4 \pm 4.5$ & $28.8(38.8 \pm 1.8)$ & $45.6(61 \pm 3.2)^{\mathrm{ab}}$ & $0.7 \pm 0.04$ & $2.2(3 \pm 0.46)$ \\
\hline
\end{tabular}

The data represents means \pm standard error. *From 5 independent repetitions (each with 4 to 6 blastocysts).

${ }^{a}$, balues with different superscripts letters within the TE column differ significantly $(\mathrm{p}<0.05)$. ICM: internal cell mass. TE: trophectoderm.

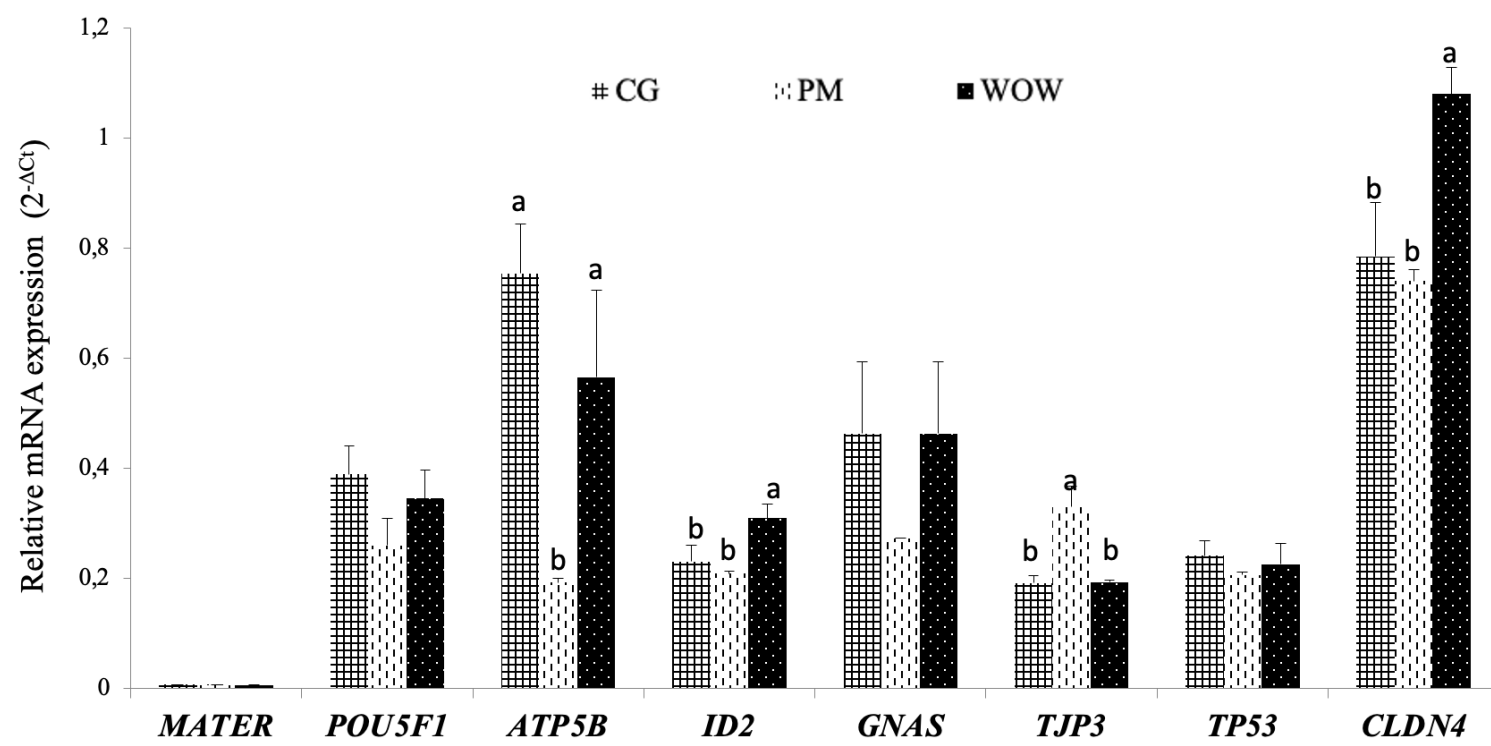

Figure 3. Effect of culture system on relative expression of MATER, POU5F1, APM5B, ID2, GNAS, TJP3 and CLDN4 genes. Data are presented as means \pm standard error of the $2-{ }^{\Delta \mathrm{Ct}}$ value of three independent experiments (each with 25 embryos). For each gene, bars with different letters differ significantly $(\mathrm{p}<0.05)$. 
This means that enough information was generated to interpret the most important aspects of the data set. The CG system was projected near degenerated embryos and expression of MATER gene; the PM system was projected near arrested embryos, higher values of ICM and TE, and expression of TJP3 gene; and the WOW system was projected toward blastocysts and morulae, as well as toward the expression of CLDN4, ID2 and GNAS genes (Figure 4).

\section{Discussion}

The most efficient way for in vitro embryo generation is by group culture (CG), but this approach makes it difficult to label or identify individual embryos, and a sudden movement of the culture dish can cause an embryo to be displaced from its original location. Here, we compared the alternative WOW and PM singleembryo culture protocols reported by Vajta et al. (2008) and Somfai et al. (2010), respectively, where embryos are maintained in defined areas but within the same cell culture medium, to the CG culture system for development of bovine embryos.

Initially, we found that all systems developed similar blastocyst yields. This is interesting because either WOW or PM single-embryo cultures have the ability to generate the same yields that conventional group culture. The WOW system allows each embryo to develop and maintain its own microenvironment, but still sharing autocrine and/or paracrine factors secreted by neighboring embryos (Dai et al., 2012). In addition to this, the partial opening to each micro-well allows for the provision of nutrients and dilution of toxic factors such as ammonia and free radicals (Vajta etal., 2008). The PM system allows embryos to stay in the same microenvironment, and the opening of polyester mesh sections allow the free pass of autocrine and/or paracrine factors (Somfai et al., 2010).

Biplot (axis PC1 y PC2: $100.00 \%$ )

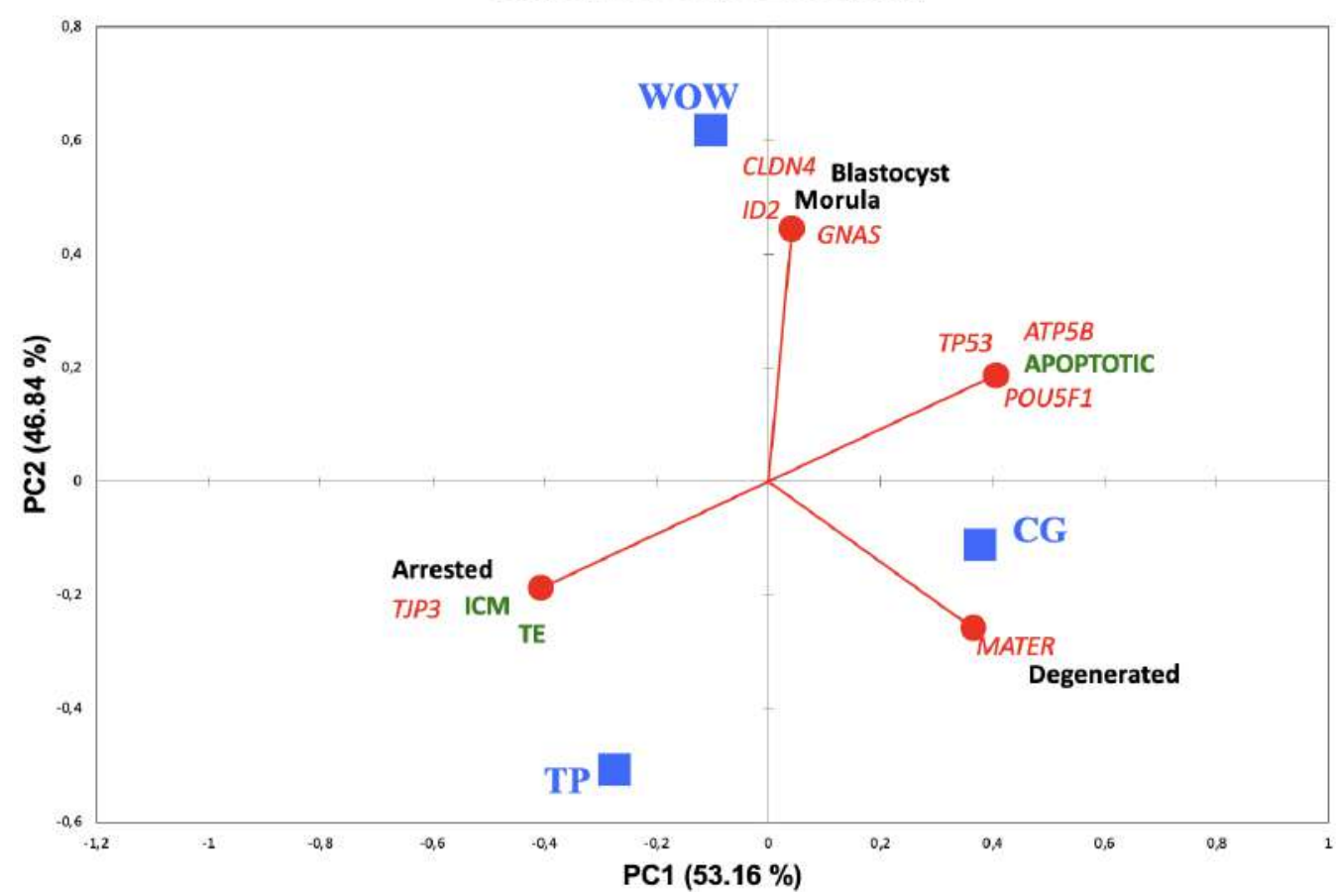

Figure 4. Relationships between culture system and class of embryos developed, type of blastocyst cells, and genes expressed 7 days post-IVF. Blue squares represent three different culture systems (CG, PM and WOW) and circles are the variables: black text designates class of embryos (blastocyst, morula, arrested and degenerated); green text designates type of cells (apoptotic, ICM, and TE). Red lines indicate direction of each variable. PC1: principal component 1; PC2: principal component 2. 
The percentage of degenerated embryos was lower in WOW compared to PM and CG systems. Although WOW system yielded the highest percentage of blastocysts, this does not mean that those blastocysts had excellent cell quality. Blastocysts comprise two different cell populations, the trophectoderm (TE) and the internal cell mass (ICM). The TE gives rise to placenta and embryonic membrane development, whereas ICM, through differentiation, generates all the tissues comprising the fetus (FouladiNashta et al., 2005). Thus, prior to implantation, a bovine blastocyst must contain 24 to 34 ICM cells, 83 to 91 TE cells and a minimum of 2 apoptotic cells (Fouladi-Nashta et al., 2005; Thouas et al., 2001). The blastocysts obtained in the three evaluated systems exhibited an adequate amount of ICM and apoptotic cells; in regards to TE cells, the blastocysts obtained in PM showed higher number $(\mathrm{p}>0.05)$ of these cells compared to CG and WOW systems. A lower number of TE cells during early embryogenesis has been related with detrimental placental development (Maylem et al., 2017; Meo et al., 2007). An increase of TE cells has a positive effect on pregnancy establishment (Lopera-Vasquez et al., 2017). This supposes an advantage of PM over WOW and GC systems.

The type of in vitro culture is the most critical factor in producing bovine embryos (Corcoran et al., 2006), since it has a direct impact on the phenotype developed by an embryo, and is closely related to the successful development of a blastocyst viable for transfer (El-Aziz et al., 2016). A phenotype modification means a shift in the expression of genes and proteins in early embryos leading to changes in fetal growth, physiological and endocrine parameters after born that affect psychosocial and psychomotor development during life (Sunde, 2019). In ruminants, in vitro embryo culture protocols have been related with alterations in phenotype, such as increased birth weight, gestational length, perinatal death, and large offspring syndrome (Sunde, 2019). In cattle, in vitro production of embryos is influenced by breed; Bos indicus generates greater blastocyst yield than Bos taurus cows (GuimarÂes et al., 2020).
Additionaly, Bos indicus embryos are more tolerant to heat shock $\left(41^{\circ} \mathrm{C}\right)$ than Bos taurus embryos (Monteiro et al., 2018; Paula-Lopes et al., 2013). However, in comparison with Bos taurus, Bos indicus embryos have greater amount of reactive oxygen species (ROS), and this is exacerbated after the cryopreservation process, which causes cell damage and affects embryo viability (Lopez-Damian et al., 2020). Cell culture conditions may negatively affect gene expression profiles and imprinting patterns, even when a blastocyst appears to be successfully developing, based on its cleavage rate and morphological appearance (Khosla et al., 2001). The environment generated is key for embryos to regulate the expression of genes that allow phenomena such as first cell divisions, activation of embryonic genome, morula compaction, and blastocyst formation and expansion (Adjaye et al., 2007; Kues et al., 2008). To ascertain which culture system had the highest amount of embryonic gene expression, we quantified the relative mRNA levels of genes POUF5F1, ATP5B, ID2, GNAS, TJP3, TP53 and CLDN4, using the null expression of maternal mRNA MATER as negative control.

The capacity of blastocysts to direct differentiation of two types of cell lineage, ICM and TE, is regulated by a precise molecular control that involves activation of specific genes for each lineage (Guo et al., 2010). Thus, in most mammalian species, such as human, mouse, porcine and bovine, formation and pluripotent maintenance of ICM is correlated with the expression of POUF5F1 transcription factor (Kirchhof et al., 2000; Schiffmacher and Keefer, 2013; Van Eijk et al., 1999); however, in bovine and porcine models, the expression of $P O U F 5 F 1$ is also correlated with TE, but at a lower rate than for ICM (Kirchhof et al., 2000). Therefore, expression of POUF5F1 gene is indispensable for cell differentiation in the blastocyst (Roberts et al., 2004). Another gene related to TE cell phenotype is $I D-2$, whose expression is required for maintenance and differentiation of these cells (Garcia et al., 2017) and is key for blastocyst implantation (Roberts et al., 2004; Xie et al., 2013). In the present study, we found neither a 
significant difference nor a statistical trend for POUF5F1 expression across the three culture systems. This implies that embryos obtained from WOW and PM are very similar to those developed in CG system in terms of POUF5F1 expression; therefore, we can be confident that embryos produced by single-embryo systems have proper differentiation of ICM and TE cell lineage. In the case of ID2 gene, the relative expression of mRNA was higher $(p<0.05)$ in WOW than in PM and CG systems; this suggests that blastocysts generated in WOW may have higher implantation capacity. The biggest challenge of in vitro embryo production is low pregnancy rate. The percentage of postimplantation embryo loss is $70-80 \%$ (Corcoran et al., 2006; Goovaerts et al., 2010; Scanavez et al., 2013), thus it is possible that WOW could help improve this embryo wastage.

The environment created in in vitro culture systems may alter genomic imprinting patterns, with deleterious consequences for embryo development (Thurston et al., 2008). After fertilization, epigenetic reprogramming generates DNA methylation patterns that are necessary for activation or silencing of specific genes to drive normal embryonic development (Urrego et al., 2014). Specifically, largescale genome demethylation occurs after fertilization, where most methyl groups -except those in the imprinting control regions (ICRs)- are eliminated from the DNA before the morula stage. Subsequently, de novo methylation occurs in the blastocyst, coinciding with ICM and TE differentiation, where ICM is hypermethylated while TE is hypomethylated (Piedrahita, 2011). The GNAS is an imprinting gene located in an ICR. It codes for the $\square$ subunit of guanine nucleotidebinding protein Gs, which stimulates adenylate cyclase activation after hormonal stimulation and also cyclic adenosine monophosphate (cAMP) production for downstream cellular signal transduction pathways (Khatib, 2004; Sikora et al., 2011). In bovines, GNAS relative expression is maintained at a low level from 2-cell until morula stage and then it increases to high expression levels in blastocyst stage (Jiang et al., 2015; Ruddock et al., 2004). In the present study, we found that relative GNAS expression was not significantly different among the three culture systems, although its expression appeared to be consistently lower in PM. This could imply that the PM system creates a more detrimental environment for GNAS expression; if so, this system could have a negative influence on the genomic imprinting process.

A key point for embryonic development is the energy contribution by mitochondria, which, by means of oxidative phosphorylation, generate most of the ATP required by the growing embryo (Roth, 2018). Gene ATP5B codes for a subunit of the F1 component of ATP synthase, comprising complex $\mathrm{V}$ of the oxidative phosphorylation machinery in the electron carrier chain in the mitochondrial membrane (Bougarn et al., 2011; Gad et al., 2012). Our results show that the expression of this gene was lower in PM than in WOW and CG systems; this suggests that embryos may be affected in their mitochondrial metabolism in PM, which could lead to diminished energy capacity.

Apoptosis is considered a normal event in early embryogenesis, necessary to eliminate abnormal cells that may compromise embryo viability (Betts and King, 2001). During bovine embryonic development there is an initial wave of apoptosis at the 9- to 16-cell stage, which later decreases in morula stage and resumes in blastocyst stage (Byrne et al., 1999). Damaged embryo DNA can be reflected by increased expression of TP53 gene, whose protein (p53) acts as a transcription factor to activate expression of the apoptotic gene $B A X$. In turn, $B A X$ protein acts directly on mitochondrial membrane permeability to liberate cytochrome c, which in turn activates caspase 9, triggering apoptosis (Betts and King, 2001). Thus, in order for an embryo to develop normally it must have an adequate amount of p53 (Liang et al., 2008). The results of the present study show that relative expression of TP53 was very similar in the three culture systems. This indicates that embryos grown in both WOW and PM have adequate expression of TP53, similar to that of embryos cultured in the CG system. This 
matches the number of apoptotic blastomeres observed by TUNEL.

The first epithelial structure that arises during early embryo development is TE, which covers the blastocyst surface, surrounds the ICM, and generates the blastocoel cavity by transporting ions, water and other small molecules across its epithelium (Fleming et al., 2001). The TE allows the passage of these molecules to the interior of the blastocoel through the action of transmembrane carriers such as $\mathrm{Na}^{+} \mathrm{K}^{+}$-ATPase, aquaporins and tight junctions (Furuse and Moriwaki, 2009). In this way, TE works as a barrier isolating ICM from the uterine environment (Moriwaki et al., 2007). Tight junctions become visible around the late morula stage, and in the blastocyst stage they circumscribe TE cells as belts to seal the intercellular space of adjacent cells and create permeability barriers that regulate passage of molecules and ions through a paracellular pathway (González-Mariscal et al., 2011; Moriwaki et al., 2007). Tight junctions are comprised of transmembrane proteins, such as ocludin and claudins, that join inside the cell with peripheral membrane proteins TJP1, TJP2, and TJP3, located toward the cytoplasm, which in turn interact with the actin cytoskeleton and also recruit factors involved in signal transduction and regulation of proliferation and differentiation (Moriwaki et al., 2007). These tight junction transmembrane proteins couple in homo- and/or heterotypic interactions with cognate proteins on the surface of adjacent cells to form the paracellular barrier (Kiener et al., 2007). Tight junctions with claudin-4 appear to seal the intercellular space ofTE, where they form aqueous and ion-selective aqueous pores, and contribute to fluid accumulation in the blastocoel cavity, which becomes expanded by elevated hydrostatic pressure (Furuse and Moriwaki, 2009; Serafini et al., 2009). Here, we examined the expression of CLDN4 and TJP3 genes, which code for tight junction proteins. Our results show that CLDN4 expression was significantly higher in WOW, whereas TJP3expression was higher in the PM system. This implies that both single-embryo culture systems have the capacity for developing blastocysts with adequate TE conformation. However, since claudin-4 is necessary for blastocyst expansion, it is possible that blastocysts developed in WOW may have higher capacity for adequate TE generation to allow adequate delimitation of the ICM zone.

In conclusion, compared with the standard CG system, both PM and WOW systems are good options for culturing single, identifiable embryos in the bovine model. This can be considered as an opportunity to improve selectivity of in vitro produced embryos.

\section{Declarations}

\section{Funding}

This study was supported by Grant 216179 from Consejo Nacional de Ciencia y Tecnología (CONACYT). D. Contreras-Benicio was a scholarship recipient from CONACYT, Mexico.

\section{Conflict of interest}

The authors declare they have no conflicts of interest with regard to the work presented in this report.

\section{Author contributions}

M.Eduviges Burrola-Barraza designed the study; Daniel Contreras-Benicio and Beatriz Elena Castro-Valenzuela conducted the study; and J.A. Grado-Ahuir performed the statistical analysis.

\section{References}

Adjaye J, Herwig R, Brink TC, Herrmann D, Greber B, Sudheer S, Groth D, Carnwath JW, Lehrach H, Niemann H. Conserved molecular portraits of bovine and human blastocysts as a consequence of the transition from maternal to embryonic control of gene expression. Physiol Genomics 2007; 31(2):315-327. http://doi.org/10.1152/physiolgenomics.00041.2007

Betts D, King W. Genetic regulation of embryo death and senescence. Theriogenology 2001; 55(1):171-191. https://doi.org/10.1016/S0093-691X(00)00453-2 
Bougarn S, Cunha P, Gilbert FB, Meurens F, Rainard P. Technical note: Validation of candidate reference genes for normalization of quantitative PCR in bovine mammary epithelial cells responding to inflammatory stimuli. J Dairy Sci 2011; 94(5):2425-2430. http://doi.org/10.3168/jds.2010-3859

ByrneA, Southgate J, Brison D, Leese H.Analysis ofapoptosisin the preimplantationbovine embryo using TUNEL. Repro 1999; 117(1):97-105. https://doi.org/10.1530/jrf.0.1170097

Corcoran D, Fair T, Park S, Rizos D, Patel OV, Smith GW, Coussens PM, Ireland JJ, Boland MP, Evans AC, Lonergan P. Suppressed expression of genes involved in transcription and translation in in vitro compared with in vivo cultured bovine embryos. Repro 2006; 131(4):651-660. http://doi.org/10.1530/rep.1.01015

Dai SJ, Xu CL, Wang J, Sun YP, Chian RC. Effect of culture medium volume and embryo density on early mouse embryonic development: tracking the development of the individual embryo. J Assist Reprod Genet 2012; 29(7):617-623. http://doi.org/10.1007/s10815-012-9744-8

Ealy AD, Wooldridge LK, McCoski SR. Board invited review: Post-transfer consequences of in vitro-produced embryos in cattle. J Anim Sci 2019; 97(6):2555-2568. http://doi.org/10.1093/jas/skz116

El-Aziz AHA, Mahrous UE, Kamel SZ, Sabed AA. Factors Influencing in vitro Production of Bovine Embryos: A Review. Asian J Anim Vet Adv 2016; 11(12):737-756. http://doi.org/10.3923/ajava.2016.737.756

Fleming TP, Sheth B, Fesenko I. Cell adhesion in the preimplantation mammalian embryo and its role in trophectoderm differentiation and blastocyst morphogenesis. Front Biosci 2001; 6(3):D1000-1007. https://doi.org/10.2741/fleming

Fouladi-Nashta A, Alberio R, Kafi M, Nicholas B, Campbell K, Webb R. Differential staining combined with TUNEL labelling to detect apoptosis in preimplantation bovine embryos. Reprod Biomed Online 2005; 10(4):497-502. https://doi.org/10.1016/S1472-6483(10)60827-9

FujitaT,UmekiH, ShimuraH, KugumiyaK, Shiga $\mathrm{K}$. Effect of group culture and embryo-culture conditioned medium on development of bovine embryos. J Reprod Dev 2006; 52(1):137-142. https://doi.org/10.1262/jrd.16084

Furuse M, Moriwaki K. The role of claudinbased tight junctions in morphogenesis. Ann N Y Acad Sci 2009; 1165:58-61. http://doi.org/10.1111/j.1749-6632.2009.04441.x

Gad A, Schellander K, Hoelker M, Tesfaye D. Transcriptome profile of early mammalian embryos in response to culture environment. Anim Reprod Sci 2012; 134(1-2):76-83. http:// doi.org/10.1016/j.anireprosci.2012.08.014

Garcia EV, Hamdi M, Barrera AD, SanchezCalabuig MJ, Gutierrez-Adan A, Rizos D. Bovine embryo-oviduct interaction in vitro reveals an early cross talk mediated by BMP signaling. Repro 2017; 153(5):631-643. http://doi.org/10.1530/REP-16-0654

González-Mariscal L, Quirós M, DiazCoranguez M. ZO proteins and redoxdependent processes. Antioxidants \& redox signaling 2011; 15(5):1235-1253. http://doi.org/10.1089/ars.2011.3913

Goovaerts IG, Leroy JL, Jorssen EP, Bols PE. Noninvasive bovine oocyte quality assessment: possibilities of a single oocyte culture. Theriogenology 2010; 74(9):1509-1520. http://doi.org/10.1016/j.theriogenology.2010.06.022

Gopichandran N, Leese HJ. The effect of paracrine/autocrine interactions on the in vitro culture of bovine preimplantation embryos. Repro 2006; 131(2):269-277. http://doi.org/10.1530/rep.1.00677

GuimarÃes ASB, Rocha LF, Jesus RDLd, Vasconcelos GL, Anghinoni G, Santana ALA, Barbosa LP. In vitro performance of Zebu (Bos indicus) and Taurus (Bos taurus) donor cow embryos. 
Rev bras saúde prod anim 2020; 21(1):1-11. http://doi.org/10.1590/s1519-994021200142020

Guo G, Huss M, Tong GQ, Wang C, Sun LL, Clarke ND, Robson P. Resolution of cell fate decisions revealed by single-cell gene expression analysis from zygote to blastocyst. Dev Cell 2010; 18(4):675-685. https://doi.org/10.1016/j.devcel.2010.02.012

Hansen PJ. Implications of Assisted Reproductive Technologies for Pregnancy Outcomes in Mammals. Annu Rev Anim Biosci 2020a; 8:395-413. http://doi.org/10.1146/annurev-animal-021419-084010

Hansen PJ. The incompletely fulfilled promise of embryo transfer in cattle-why aren't pregnancy rates greater and what can we do about it? J Anim Sci 2020b; 98(11):skaa288. http://doi.org/10.1093/jas/skaa288

Jiang Z, Dong $\mathrm{H}$, Zheng $\mathrm{X}$, Marjani SL, Donovan DM, Chen J, Tian XC. mRNA levels of imprinted genes in bovine in vivo oocytes, embryos and cross species comparisons with humans, mice and pigs. Sci Rep 2015; 5(1):1-10. http://doi.org/10.1038/srep17898

Khatib H. Imprinting of Nesp55 gene in cattle. Mamm Genome 2004; 15(8):663-667. http://doi.org//10.1007/s00335-004-2331-2

Khosla S, Dean W, Reik W, Feil R. Culture of preimplantation embryos and its long-term effects on gene expression and phenotype. Hum Reprod Update 2001; 7(4):419-427. https://doi.org/10.1093/humupd/7.4.419

Kiener TK, Sleptsova-Friedrich I, Hunziker W. Identification, tissue distribution and developmental expression of tjp1/zo-1, tjp2/ zo-2 and tjp3/zo-3 in the zebrafish, Danio rerio. Gene Expr Patterns 2007; 7(7):767-776. http://doi.org/10.1016/j.modgep.2007.05.006

KirchhofN, Carnwath J, Lemme E, Anastassiadis K, Scholer H, Niemann H. Expression pattern of Oct-4 in preimplantation embryos of different species. Biol Reprod 2000; 63(6):1698-1705. https://doi.org/10.1095/biolreprod63.6.1698
Komori K, Fujii S, Montagne K, Nakamura H, Kimura H, Otake K, Fujii T, Sakai Y. Development of a well-of-the-well systembased embryo culture plate with an oxygen sensing photoluminescent probe. Sens Actuators B Chem 2012; 162(1):278-283. http://doi.org/10.1016/j.snb.2011.12.078

Kues W, Sudheer S, Herrmann D, Carnwath J, Havlicek V, Besenfelder U, Lehrach $\mathrm{H}$, Adjaye J, Niemann H. Genome-wide expression profiling reveals distinct clusters of transcriptional regulation during bovine preimplantation development in vivo. Proc Natl Acad Sci USA 2008; 105(50):19768-19773. https://doi.org/10.1073/pnas.0805616105

Liang M, Ayanga B, Du S, Godwin AK, Hartsock JK, Evans SC. Ovca1, a candidate gene of the genetic modifier of Tp53, Mop2, affects mouse embryonic lethality. Genes Chromosom Cancer 2008; 47(4):315-325. https://doi.org/10.1002/gcc.20535

Livak KJ, Schmittgen TD. Analysis of relative gene expression data using realtime quantitative PCR and the 2(-Delta Delta C(T)) Method. Methods 2001; 25(4):402-408. http://doi.org/10.1006/meth.2001.1262

Lopera-Vasquez R, Hamdi M, Maillo V, Lloreda V, Coy P, Gutierrez-Adan A, Bermejo-Alvarez P, Rizos D. Effect of bovine oviductal fluid on development and quality of bovine embryos produced in vitro. Reprod Fertil Dev 2017; 29(3):621-629. http://doi.org/10.1071/RD15238

Lopes JS, Alcazar-Trivino E, Soriano-Ubeda C, Hamdi M, Canovas S, Rizos D, Coy P. Reproductive Outcomes and Endocrine Profile in Artificially Inseminated versus Embryo Transferred Cows. Animals 2020; 10(8):1-14 http://doi.org/10.3390/ani10081359

Lopez-Damian EP, Jimenez-Medina JA, Alarcon MA, Lammoglia MA, Hernandez A, Galina CS, Fiordelisio T. Cryopreservation induces higher oxidative stress levels in Bos indicus embryos compared with Bos 
taurus. Theriogenology 2020; 143:74-81. http://doi.org/10.1016/j.theriogenology.2019.12.001

Marianowski P, Szymusik I, Grzechocinska B, Cyganek A. The comparison of two different embryo culture methods in the course of in vitro fertilization program. Folia Histochem Cytobiol 2007; 45(I):115-117.

Maylem ERS, Leoveras MED, Atabay EC, Atabay EP. Assessing the Quality of Bovine Embryos Produced In Vitro Through the Inner Cell Mass and Trophectoderm Ratio. Philipp J Sci 2017; 146(4):469-474.

Meo SC, Yamazaki W, Ferreira CR, Perecin F, Saraiva NZ, Leal CL, Garcia JM. Parthenogenetic activation of bovine oocytes using single and combined strontium, ionomycin and 6-dimethylaminopurine treatments. Zygote 2007; 15(4):295-306. http://doi.org/10.1017/S0967199407004285

Monteiro F, Freitas E, Melo D, Carvalho L, Teixeira A, Coelho L, Trinca L, Barros C. Resistance of embryos from Bos indicus cattle during early stages of in vitro development to heat shock compared to embryos crossbred from crossbred cattle. Anim Reprod 2018; 4(1):51-58.

Moriwaki K, Tsukita S, Furuse M. Tight junctions containing claudin 4 and 6 are essential for blastocyst formation in preimplantation mouse embryos. Dev Biol 2007; 312(2):509-522. https://doi.org/10.1016/j.ydbio.2007.09.049

Paria B, Dey S. Preimplantation embryo development in vitro: cooperative interactions among embryos and role of growth factors. Proc Natl Acad Sci USA 1990; 87(12):4756-4760. https://doi.org/10.1073/pnas.87.12.4756

Paula-Lopes F, Lima RSd, Satrapa RA, Barros CM. Physiology and endocrinology symposium: influence of cattle genotype (Bos indicus vs. Bos taurus) on oocyte and preimplantation embryo resistance to increased temperature. J Anim Scie 2013; 91(3):1143-1153. https://doi.org/10.2527/jas.2012-5802
Piedrahita JA. The role of imprinted genes in fetal growth abnormalities. Birth Defects Res A Clin Mol Teratol 2011; 91(8):682-692. https://doi.org/10.1002/bdra.20795

Roberts RM, Ezashi T, Das P. Trophoblast gene expression: transcription factors in the specification of early trophoblast. Reprod Biol Endocrinol 2004; 2(1):1-9. http://doi.org/10.1186/1477-7827-2-47

Roth Z. Stress-induced alterations in oocyte transcripts are further expressed in the developing blastocyst. Mol Reprod Dev 2018; 85(11):821-835. https://doi.org/10.1002/mrd.23045

Ruddock NT, Wilson KJ, Cooney MA, Korfiatis NA, Tecirlioglu RT, French AJ. Analysis of imprinted messenger RNA expression during bovine preimplantation development. Biol Reprod 2004; 70(4):1131-1135. https://doi.org/10.1095/biolreprod.103.022236

Salvador I, Cebrian Serrano A, Salamone DF, Silvestre M. Effect of number of oocytes and embryos on in vitro oocyte maturation, fertilization and embryo development in bovine. Span J Agric Res 2011; 9(3):744-752.

Scanavez A, Campos C, Santos R. Pregnancy and pregnancy loss rates in recipients of bovine embryos produced in vitro. Arq Bras Med Vet Zootec 2013; 65(3):722-728. https://doi.org/10.1590/S0102-09352013000300017

Schiffmacher AT, Keefer CL. CDX2 regulates multiple trophoblast genes in bovine trophectoderm CT-1 cells. Mol Reprod Dev 2013; 80(10):826-839. https://doi.org/10.1002/mrd.22212

Serafini PC, Silva ID, Smith GD, Motta EL, Rocha AM, Baracat EC. Endometrial claudin-4 and leukemia inhibitory factor are associated with assisted reproduction outcome. Reprod Biol Endocrinol 2009; 7(1):1-9. http://doi.org/10.1186/1477-7827-7-30 
Sikora KM, Magee DA, Berkowicz EW, Berry DP, Howard DJ, Mullen MP, Evans RD, MacHugh DE, Spillane C. DNA sequence polymorphisms within the bovine guanine nucleotide-binding protein Gs subunit alpha (Gs $\alpha$ )-encoding (GNAS) genomic imprinting domain are associated with performance traits. BMC Genet 2011; 12(1):4.

Somfai T, Inaba Y, Aikawa Y, Ohtake M, Kobayashi S, Akai T, Hattori H, Konishi $\mathrm{K}$, Imai $\mathrm{K}$. Culture of bovine embryos in polyester mesh sections: the effect of pore size and oxygen tension on in vitro development. Reprod Domest Anim 2010; 45(6):1104-1109. http://doi.org/10.1111/j.1439-0531.2009.01502.x

Sugimura S, Akai T, Hashiyada Y, Somfai T, Inaba Y, Hirayama M, Yamanouchi T, Matsuda H, Kobayashi S, Aikawa Y, Ohtake M, Kobayashi E, Konishi K, Imai K. Promising system for selecting healthy in vitro-fertilized embryos in cattle. PLoS One 2012; 7(5):e36627. http://doi.org/10.1371/journal.pone.0036627

Sugimura S, Akai T, Somfai T, Hirayama M, Aikawa Y, Ohtake M, Hattori H, Kobayashi S, Hashiyada Y, Konishi K, Imai K. Time-lapse cinematography-compatible polystyrene-based microwell culture system: a novel tool for tracking the development of individual bovine embryos. Biol Reprod 2010; 83(6):970-978. http://doi.org/10.1095/biolreprod.110.085522

Thouas GA, Korfiatis NA, French AJ, Jones GM, Trounson AO. Simplified technique for differential staining of inner cell mass and trophectoderm cells of mouse and bovine blastocysts. Reprod Biomed Online 2001; 3(1):25-29. http://doi.org/10.1016/s1472-6483(10)61960-8

Thurston A, Taylor J, Gardner J, Sinclair KD, Young LE. Monoallelic expression of nine imprinted genes in the sheep embryo occurs after the blastocyst stage. Repro 2008; 135(1):29. http://doi.org/10.1530/REP-07-0211

Urrego R, Rodriguez-Osorio N, Niemann $\mathrm{H}$. Epigenetic disorders and altered gene expression after use of assisted reproductive technologies in domestic cattle. Epigenetics 2014;9(6):803-815. http://doi.org/10.4161/epi.28711

Vajta G, Korösi T, Du Y, Nakata K, Ieda S, Kuwayama M, Nagy ZP. The Well-ofthe-Well system: an efficient approach to improve embryo development. Reprod Biomed Online 2008; 17(1):73-81. https://doi.org/10.1016/S1472-6483(10)60296-9

Vajta G, Peura T, Holm P, Paldi A, Greve T, Trounson A, Callesen H. New method for culture of zona-included or zona-free embryos: The Well of the Well (WOW) system. Mol Reprod Dev 2000; 55(3):256-264.

Vajta G, Rienzi L, Bavister BD. Zonafree embryo culture: is it a viable option to improve pregnancy rates? Reprod Biomed Online 2010a; 21(1):17-25. https://doi.org/10.1016/j.rbmo.2010.03.014

Vajta G, Rienzi L, Cobo A, Yovich J. Embryo culture: can we perform better than nature? Reprod Biomed Online 2010b; 20(4):453-469. https://doi.org/10.1016/j.rbmo.2009.12.018

Van Eijk M, Van Rooijen M, Modina S, Scesi L, Folkers G, Van Tol H, Bevers M, Fisher S, Lewin H, Rakacolli D. Molecular cloning, genetic mapping, and developmentalexpression ofbovine POU5F1. Biol Reprod 1999; 60(5):1093-1103. https://doi.org/10.1095/biolreprod60.5.1093

Xie Y, Awonuga A, Liu J, Rings E, Puscheck EE, Rappolee DA. Stress induces AMPKdependent loss of potency factors $I d 2$ and $\mathrm{Cdx} 2$ in early embryos and stem cells [corrected]. Stem Cells Dev 2013; 22(10):1564-1575. https://doi.org/10.1089/scd.2012.0352 